http://jmscr.igmpublication.org/home/ ISSN (e)-2347-176x ISSN (p) 2455-0450 crossref DOI: https://dx.doi.org/10.18535/jmscr/v7i8.72

\title{
Morbidity pattern of patients attending psychiatry outpatient department in state mental health and rehabilitation center of a northern state of India
}

\author{
Authors \\ Vineet Kumar ${ }^{1}$, Sanjay Pathak ${ }^{2}$, Vikesh Gupta ${ }^{3 *}$ \\ ${ }^{1}$ OSD, Directoreate of Health Services,Shimla, Himachal Pradesh. \\ ${ }^{2}$ Senior Medical Superintendent, HHMH \& R, Shimla, Himachal Pradesh. \\ ${ }^{3}$ Medical Officer (Psychiatry), HHMH \& R, Shimla, Himachal Pradesh. \\ *Corresponding Author \\ Vikesh Gupta \\ Medical Officer (Psychiatry), HHMH \& R, Shimla, Himachal Pradesh, India
}

\begin{abstract}
WHO data on global burden of diseases says that mental illnesses accounts for over 15 percent of the total burden of disease. This study was planned to describe the common psychiatric disorders and various sociodemographic variables associated among patients attending psychiatry Out Patient Department $(O P D)$ at a tertiary care psychiatric hospital of a northern state of India. This was a cross sectional record-based study. Psychiatric diagnosis was made according to International Classification of Diseases classification -10. In our study we analysed data of 153 patients who were first time registered in OPD of $H H M H \& R$ Shimla in last one year. We found that most of patients were in age group of 18-40years of age $(51.0 \%)$ and $73.2 \%$ patients were males. In our study we observed that $55.6 \%$ patients were married, $32.0 \%$ were single and $12.4 \%$ were separated. In our findings most of patients (39.2\%) had no history of co-morbid substance abuse however most common co-morbid substance abuse was both cannabis and tobacco. Schizophrenia was the most common psychiatric illness found in our study. Mental health disorders were found majorly in younger, unemployed males. While forming mental health policies Government should take these findings in consideration.

Keywords: Mental health disorders, morbidity pattern, cross-sectional study, ICD 10, scizophrenia.
\end{abstract}

\section{Introduction}

Mental health policy makers in India from time to time estimated the prevalence of psychiatric disorders in the country. The data helps in understanding the status of mental health in the country and in planning for prevention and treatment of disorders. ${ }^{1}$ WHO data on global burden of diseases says that mental illnesses accounts for over 15 percent of the total burden of disease. $^{2}$ National all-India prevalence rates for 'all mental disorders' is 70.5 (rural), 73 (urban) and 73 (rural + urban) per 1000 persons. ${ }^{1}$ Urban morbidity is $3.5 \%$ higher than the rural area. Surveys in developed as well as developing countries reported more than $25 \%$ of individuals with one or more mental or behavioral disorders, during their life time. ${ }^{3}$ A study from Nepal, (2011) reported Schizophrenia as one of the most common psychiatric illness in Psychiatry ward of the tertiary care hospital and psychotic disorders being the second. ${ }^{4}$ A study from South Africa reported lifetime prevalence of common mental 
health disorders about $30 \% .^{5}$ The Ministry of Health and Family welfare of India suggested the lifetime prevalence of mental disorders nearly 12 $\%$ which is likely to increase to almost $15 \%$ by the year 2020. ${ }^{6}$

Himachal Pradesh, the northern state of India is a hilly state. Due to geographical constrains this state has only one mental hospital that is Himachal Hospital of Mental Health and Rehabilitation (HHMH\&R) situated at Shimla which is also capital of state. This study was planned todescribe the common psychiatric disorders and various sociodemographic variables associated among patients attending psychiatry Out Patient Department (OPD) at this center.

\section{Materials and Methods}

This was a cross sectional record-based study. All the consecutive patients who reported to the OPD of hospital during January 2018 through December 2018 were included in the study. Information regarding various sociodemographic variable of patients was taken using pre-designed structured proforma. Psychiatric diagnosis was made according to International Classification of Diseases classification $-10 .{ }^{7}$ Data regarding various sociodemographic and clinical variables of patients was collected from treatment records of patients according to study tool as described above. Data was analyzed using Epi Info software version 7.2.2. Data was presented as frequencies, percentages and their 95\% Confidence Intervals $((95 \% \mathrm{CI})$.

\section{Results}

In our study we analysed data of 153 patients who were first time registered in OPD of HHMH\&R Shimla in last one year. We found that most of patients were in age group of 18-40years of age (51.0\%). $73.2 \%$ patients were maleswhile $26.8 \%$ were females, $82.3 \%$ patients were from rural area. In our study we observed that $55.6 \%$ patients were married, $32.0 \%$ were single and $12.4 \%$ were separated. We found that most of patients $(62.8 \%)$ had duration of illness $>2$ years. More than half of our patients $(52.9 \%)$ did not know their onset of illness and $67.3 \%$ were have continuous course of illness. Majority of patients $(45.1 \%)$ were studied up to matric and $23.5 \%$ were studied up to $12^{\text {th }}$ standard. In our findings most of patients $(39.2 \%)$ had no history of comorbid substance abuse however most common co-morbid substance abuse was both cannabis and tobacco.In our study we found that most common diagnosis was schizophrenia among $36.6 \%$ of patients in last one year (July 2018 to June 2019) followed by primary diagnosis as any substance abuse disorder (14.4\%) patients and $13.1 \%$ patients was diagnosed with BPAD and Mania.

In our study we found that most common diagnosis was schizophrenia among $36.6 \%$ of patients in last one year (July 2018 to June 2019) followed by primary diagnosis as any substance abuse disorder (14.4\%)patients and $13.1 \%$ patients was diagnosed with BPAD and Mania. Table 2.

Table 1: Description of sociodemographic and clinical variables of study participants

\begin{tabular}{|l|c|c|c|}
\hline Variables & Number & Percentage (\%) & $\begin{array}{c}\text { 95\% confidential } \\
\text { Interval(CI) }\end{array}$ \\
\hline Age & 7 & 4.6 & \\
<18years & 78 & 51.0 & $1.9-9.2$ \\
18-40years & 58 & 37.9 & $32.8-59.1$ \\
40-60 years & 10 & 6.5 & $3.2-11.7$ \\
\hline >60years & & & \\
\hline Sex & 112 & 73.2 & $65.5-80.0$ \\
Male & 41 & 26.8 & $20.0-34.6$ \\
Female & & & \\
\hline Locality & 27 & 17.7 & $12.0-24.6$ \\
Urban & 126 & 82.3 & $75.4-88.0$ \\
Rural & \multicolumn{3}{|c}{} \\
\hline
\end{tabular}




\begin{tabular}{|c|c|c|c|}
\hline $\begin{array}{l}\text { Marital status } \\
\text { Single } \\
\text { Married } \\
\text { Separated } \\
\end{array}$ & $\begin{array}{l}49 \\
85 \\
19 \\
\end{array}$ & $\begin{array}{l}32.0 \\
55.6 \\
12.4 \\
\end{array}$ & $\begin{array}{c}24.7-40.0 \\
47.3-63.6 \\
7.6-18.7 \\
\end{array}$ \\
\hline $\begin{array}{l}\text { Duration of Illness } \\
\text { <1month } \\
1 \text { month-6month } \\
\text { 6months-2years } \\
>2 \text { years }\end{array}$ & $\begin{array}{c}5 \\
20 \\
32 \\
96\end{array}$ & $\begin{array}{c}3.3 \\
13.1 \\
20.9 \\
62.8\end{array}$ & $\begin{array}{c}1.1-7.5 \\
8.2-19.5 \\
14.8-28.2 \\
54.6-70.4\end{array}$ \\
\hline $\begin{array}{l}\text { Employment Status } \\
\text { Unemployed /Student } \\
\text { Unskilled } \\
\text { Semiskilled } \\
\text { Skilled }\end{array}$ & $\begin{array}{c}98 \\
27 \\
25 \\
3\end{array}$ & $\begin{array}{c}64.1 \\
17.7 \\
16.3 \\
2.0\end{array}$ & $\begin{array}{c}55.9-71.6 \\
12.0-24.6 \\
10.9-23.2 \\
0.4-5.6\end{array}$ \\
\hline $\begin{array}{l}\text { Onset of Illness } \\
\text { Up to 1wk } \\
\text { 1wk-1month } \\
>1 \text { month } \\
\text { Not known } \\
\end{array}$ & $\begin{array}{l}14 \\
28 \\
30 \\
81 \\
\end{array}$ & $\begin{array}{c}9.2 \\
18.3 \\
19.63 \\
52.9 \\
\end{array}$ & $\begin{array}{c}5.1-14.9 \\
12.5-25.4 \\
13.6-26.8 \\
44.7-61.1 \\
\end{array}$ \\
\hline $\begin{array}{l}\text { Course of illness } \\
\text { Continuous } \\
\text { Episodic } \\
\text { Fluctuating } \\
\text { Deteriorating }\end{array}$ & $\begin{array}{c}103 \\
31 \\
16 \\
3\end{array}$ & $\begin{array}{c}67.3 \\
20.3 \\
10.5 \\
2.0\end{array}$ & $\begin{array}{c}59.3-74.7 \\
14.2-27.5 \\
6.1-16.4 \\
0.4-5.6\end{array}$ \\
\hline $\begin{array}{l}\text { Education } \\
\text { Illiterate } \\
\text { Up to matric } \\
\text { Up to } 12^{\text {th }} \\
\text { Graduate } \\
\text { PG }\end{array}$ & $\begin{array}{c}19 \\
69 \\
36 \\
26 \\
3\end{array}$ & $\begin{array}{c}12.4 \\
45.1 \\
23.5 \\
17.0 \\
2.0\end{array}$ & $\begin{array}{c}7.6-18.7 \\
37.1-53.3 \\
17.1-31.1 \\
11.4-23.9 \\
0.4-5.6\end{array}$ \\
\hline $\begin{array}{l}\text { Type of Co morbid Substance } \\
\text { Abuse } \\
\text { Nil } \\
\text { Alcohol (F10) } \\
\text { Tobacco (F17) } \\
\text { Cannabis and tobacco } \\
\text { Alcohol and tobacco } \\
\text { Alcohol, tobacco and cannabis } \\
\text { Others }\end{array}$ & $\begin{array}{c}60 \\
1 \\
33 \\
34 \\
12 \\
12 \\
1\end{array}$ & $\begin{array}{c}39.2 \\
0.7 \\
21.6 \\
22.2 \\
7.8 \\
7.8 \\
0.7\end{array}$ & $\begin{array}{c}31.4-47.4 \\
0.02-3.6 \\
15.3-28.9 \\
15.9-29.6 \\
4.2-13.3 \\
4.1-13.3 \\
0.02-3.6\end{array}$ \\
\hline $\begin{array}{l}\text { Religion } \\
\text { Hindu } \\
\text { Others }\end{array}$ & $\begin{array}{c}150 \\
3\end{array}$ & $\begin{array}{c}98.0 \\
2.0\end{array}$ & $\begin{array}{c}94.4-99.6 \\
0.4-5.6\end{array}$ \\
\hline
\end{tabular}

Table 2 : Types of psychiatric disorders observed in study participants.

\begin{tabular}{|l|c|c|c|}
\hline Psychiatric Diagnosis & Number (n) & Percentage (\%) & $\mathbf{9 5 \%}$ CI \\
Schizophrenia (F20) & 56 & 36.6 & $29.0-44.8$ \\
Psychosis NOS (F29) & 7 & 4.6 & $1.9-9.2$ \\
Acute Transient Psychotic Disorder (F23) & 8 & 5.2 & $2.3-10.0$ \\
Bipolar Affective Disorder (F31) \&Mania(F30) & 20 & 13.1 & $8.2-19.5$ \\
Depression (F32) & 12 & 7.8 & $4.1-13.3$ \\
Mental Retardation [MR] (F70 to F73) & 1 & 0.7 & $0.02-3.6$ \\
Schizoaffective Disorders (F25) & 5 & 3.3 & $1.1-7.5$ \\
MR with Other Diagnosis & 3 & 2.0 & $0.4-5.6$ \\
Any substance (F10-F19) & 22 & 14.4 & $9.2-21.0$ \\
Others & 19 & 12.4 & $7.6-18.7$ \\
\hline
\end{tabular}

\section{Discussion}

In our study we found that most of patients were in age group 18-40 years of age, a study by Sunil
Nayak at el found $27.8 \%$ patients belonged to age group $20-29^{8}$ and in a study by Ayesha Sarwat at $\mathrm{el}^{9}$ more than half of patients belonged to age 
group 20-40 years. These findings are almost similar to our observations. In our study most of patients were male, most patients were married and were unemployed or doing semiskilled work, Sunil Nayak at el found $59.9 \%$ patients were males, 32\% patients belonged to laborer group followed by unemployed (26\%) and $65.5 \%$ were married, these findings were almost similar.

In our study we found that most common diagnosis among patients attending OPD at HHMH\&R is schizophrenia followed by any substance use disorder among $14.4 \%$ of patients, howerver in study by Sunil Nayak at $\mathrm{el}^{8}$, most common diagnosis is depression in $29 \%$ of patients followed by schizphrenia among $18 \%$ of patients. It can be explained due to fact that study done by sunil nayak et al was in Kesar SAL Medical College Hospital where all kind of specialities are availalble and all kind of patients present. However our institute is State mental hospital, So due to stigma and other factors only chronic patients used to attend this hospital.

\section{Conclusion}

Schizophrenia was the most common psychiatric illness found in our study. Mental health disorders were found majorly in younger, unemployed males. While forming mental health policies Government should take these findings in consideration.

\section{Funding: None}

Conflict of intrest: None

\section{References}

${ }^{1}$ H.C. Ganguli et al., Epidemiological findings on prevalence of mental disorders in India. Indian

J Psychiatry 2000; 42 (1) : 14- 20.6.

${ }^{2}$ Ustun TB, Sartorius N, eds. Mental illness in general health care: an international study. Chichester, 1995, John Wiley \& Sons behalf of WHO: 323-34
${ }^{3}$ Almeid-Filho $\mathrm{N}$ et al. Brazilian multicentric study of psychiatric morbidity. Methodological features and prevalence estimates. Br J Psychiatry 1997; 171: 524-9.

${ }^{4}$ Shrestha MR, Sherchan S, Shakya R, Joshi D. Monthly pattern of psychiatric morbidity and duration of stay among the patients admitted in Mental Hospital, a central level tertiary care hospital. Nepal Med Coll J 2011;13(2):133-39.

${ }^{5}$ Herman AA, Stein DJ, Seedat S, Heeringa SG, Moomal H, Williams DR. The South African Stress and Health (SASH) study: 12month and lifetime prevalence of common mental disorders. SAMJ: South Afri Med J 2009;9(5):339-44.

${ }^{6}$ World Health Organization 2015. International public health hazards: Indian legislative provisions. Available at URL: [http//www.who.org.indian/legis/pub.healthha z/en].

${ }^{7}$ World Health Organization (1992). ICD-10 Classification of Mental and Behavioural Disorders: Clinical Description and Diagnostic Guidelines, Geneva: World Health Organization. 